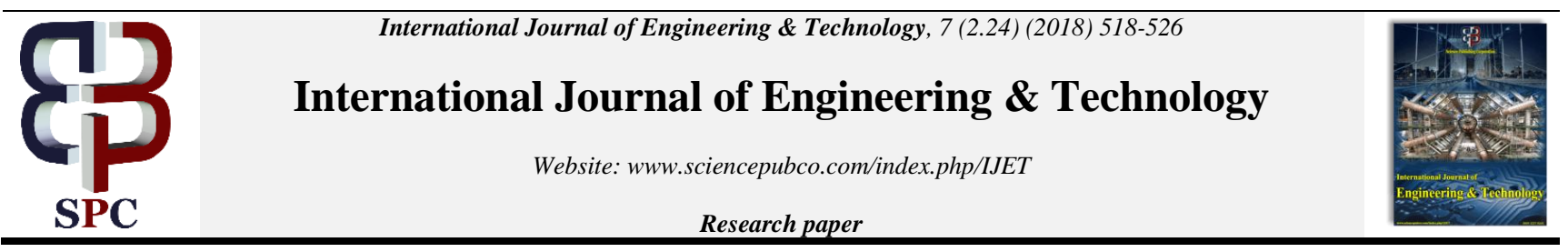

\title{
Load and Emission Characteristics of Pongamia Pinnata Oil in ACI Engine
}

\author{
V.V. Arun Sankar ${ }^{1}$, AP. Arun Pravin ${ }^{2}$, P. Suresh ${ }^{3}$ \\ ${ }^{1}$ Assistant Professor, Karpagam College of Engineering, Coimbatore-641032, India \\ ${ }^{2}$ Assistant Professor, St. Peters College of Engineering and Technology, Chennai-641032, India \\ ${ }^{3}$ Professor, Muthayammal Engineering College, Rasipuram-637408, India \\ *Corresponding Author Email: arun2386@gmail.com
}

\begin{abstract}
As the world is running on fossil fuels there has been an ever increase in the depletion rate of these fuels. A promising and a best alternate to the fossil fuel is vegetable oils. Pongamia Pinnata oil is non edible in nature and is available abundantly in India. An experimental investigation is made to evaluate the performance, emission and combustion characteristics on a compression ignition engine by using methyl ester of pongamia with mineral diesel in different proportions. Pongamia methyl ester was blended with diesel in proportions of $50 \%$ and $100 \%$ by mass and the results are tabulated and evaluated under various test conditions. The performance parameters were found to be very close to that of mineral diesel. The brake thermal efficiency and mechanical efficiency were better than mineral diesel for some specific blending ratios under certain loads. The Efficiency and emission characteristics were also studied and levels of carbon dioxide, carbon monoxide, nitric oxide and hydrocarbons were found to be equal than pure diesel.
\end{abstract}

Keywords: Alternate Fuels, Biodiesel, Alternate fuels in CI engine, Pongamia Pinnata oil, Methyl esters.

\section{Introduction}

The increased demand of petroleum derived fuel as well as their resulting environmental concerns provides the incentives for the development of alternate fuels from renewable resources. Biodiesel derived from animal fat and vegetable oils can be used as diesel fuel substitute. The conventional method for the preparation of Biodiesel consists of alkali catalysed transesterification of the low free fatty acid (FFA) oil with methanol (Malaya Naik et al, April 2008) [1] and (R. Sathish Kumar et al, 2015) [8]. Karanja is a non-edible oil seed grown throughout India is presently being underutilised (Gaurav Dwivedi et al, August 2011) [9]. Blended and transerterified Pongamia methyl ester is taken for experimental study in a CI engine by taking various blends of biodiesel (S.N Bobade et al, August 2012) [3] and (Arun K. Vuppaladadiyam et al) [4]. The present work has been undertaken with the following objectives:

- To extract oil from karanja seeds,

- $\quad$ To find the constituents of the oil,

- To explore the preparation of biodiesel,

- $\quad$ To find performance and emission parameters.

\section{Problem Analysis}

In few years the fossil fuels like petrol, diesel, are going to be very demand. Non-renewable sources of energy are derived from prehistoric fossils and are no longer available if once used. Their source is limited and are depleting at a faster rate. When extracted it poses a severe damage to the landscape as they are to be dig out from underground wells. So we need to find an alternate solution for this issue.

\subsection{Demerits of Fossil Fuels}

- environmental hazards

- $\quad$ rising prices

- acid rain

- non-renewable

- $\quad$ impact on aquatic life by oil spill

\section{Bio Diesel}

Transesterification or esterification of triglycerides or fatty acids gives Biodiesel that are renewable, biodegradable, eco-friendly and non-toxic fuel. In the recent years Biodiesel is considerably used as substitute for diesel due to depletion of fossil fuels like petroleum and coal. In India considerable efforts are being taken on the production and utilization of biodiesel. Methyl esters though being less combustive than diesel is a clean burning fuel with nil sulphur emission. No engine adjustments or modifications are needed to use this fuel and efficiency obtained is nearly similar to that obtained by using conventional diesel. Methyl esters produced at low pressure and low temperature conditions are noncorrosive in nature. Bi-product during the transesterification process is $80 \%$ concentrated glycerine. Biodiesel produced using base catalysed transesterification process is the most economical process of all. It requires low temperatures and pressures for a conversion yield $98 \%$. 


\subsection{Transesterification Process}

Transesterification is process the commonly used to produce bio diesel. Transesterification process is the reaction of a triglyceride with an alcohol to form esters and glycerol (Arun K. Vuppaladadiyam et al,) [4]. A triglyceride has a glycerine molecule as its base with three long chain fatty acids attached. The characteristics of the fat are determined by the nature of the fatty acids attached to the glycerine. The nature of the fatty acids can in turn affect the characteristics of the biodiesel. During the esterification process, the triglyceride is reacted with alcohol in the presence of a catalyst, like sodium hydroxide or potassium hydroxide (M H Attal et al, Oct 2016) [10]. The alcohol reacts with the fatty acids to form biodiesel and crude glycerol (M Rakib Uddin et al, 2017) [2]. In this research work potassium hydroxide has been used for the ethyl ester biodiesel production. Controllers for non-linear systems has been reported [11-20]

\subsection{Experimental set up for Esterification}

The experimental set up for esterification is as shown in figure 1. Three $2000 \mathrm{ml}$ round -bottom necked flask was used as a reactor. The setup is equipped with a controllable mantle in which the temperature could be controlled within $+2^{0} \mathrm{C}$ is used for heating the flask. The side necks of the flask was equipped with a condenser and a thermo well. For temperature measurement of glycerol inside the reactor a thermometer was placed in the thermo well. A motor powered stirrer with a speed regulator was used for mixing purpose.

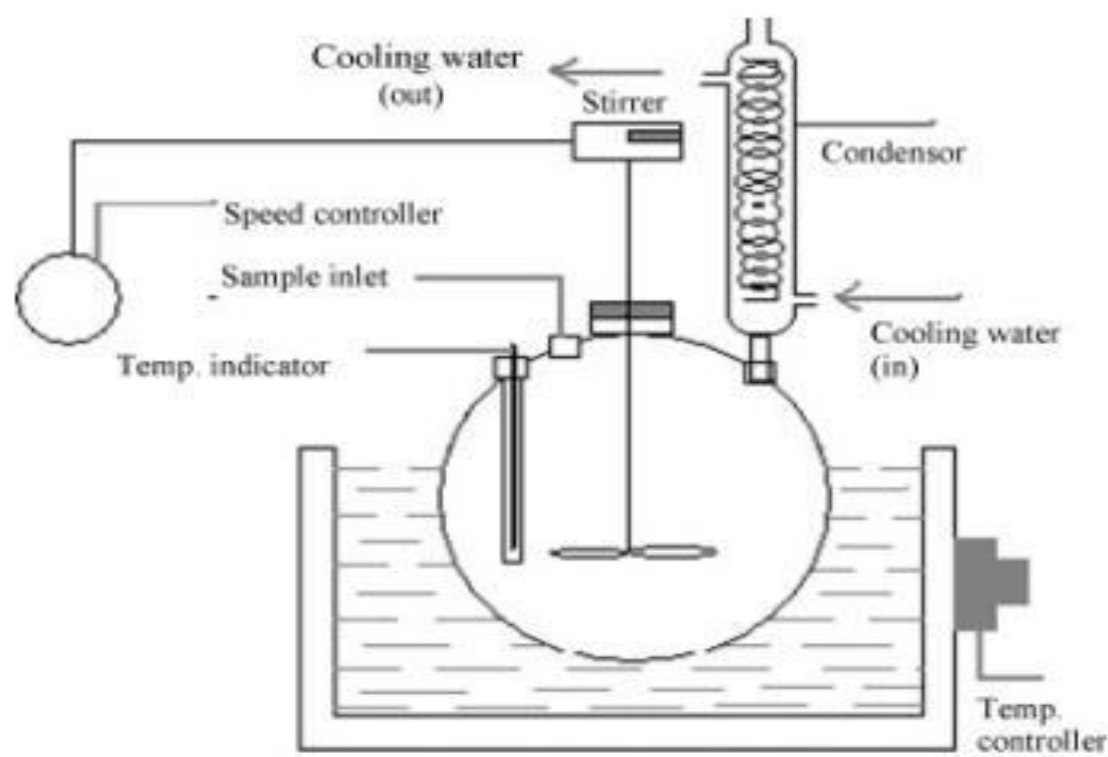

Fig. 1: Experimental setup for preparation of pongamia oil methyl ester (Biodiesel)

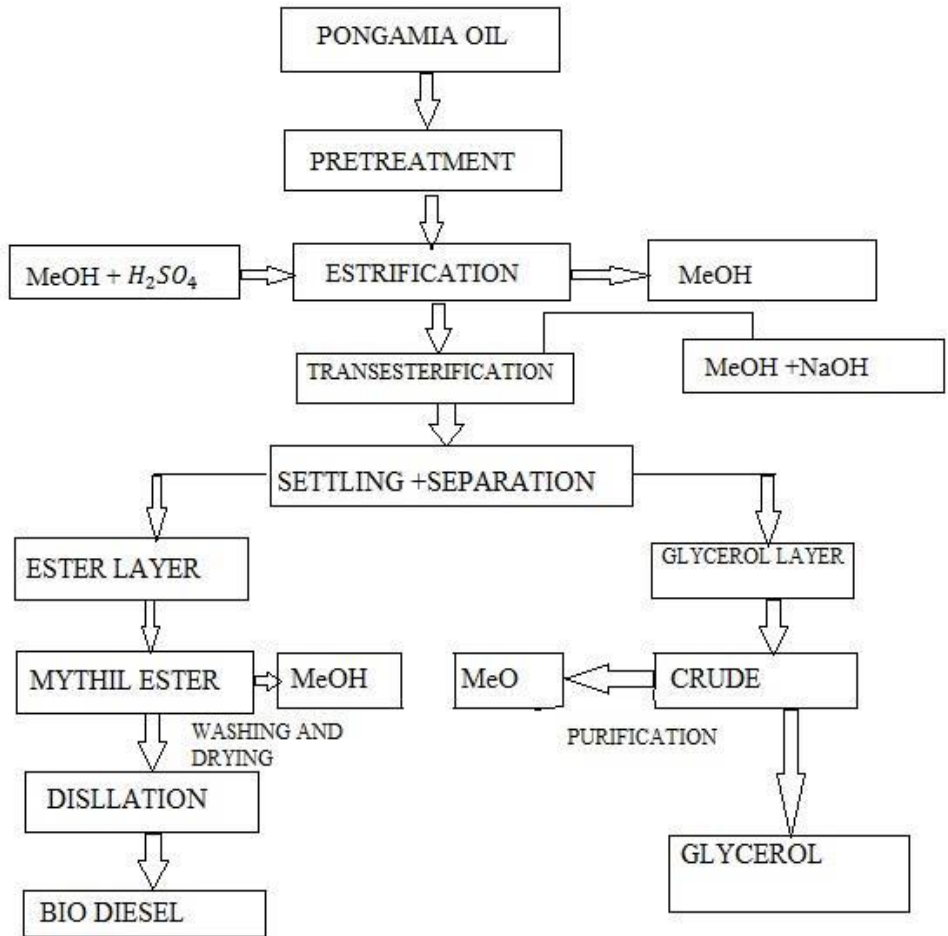

Fig. 2: Flow chart of esterification 


\section{Experimental Setup of Diesel Engine}

\subsection{Dynamometer}

Dynamometer is used to measure the fuel consumption timing .The fuel passed through dynamometer to the engine, finds the

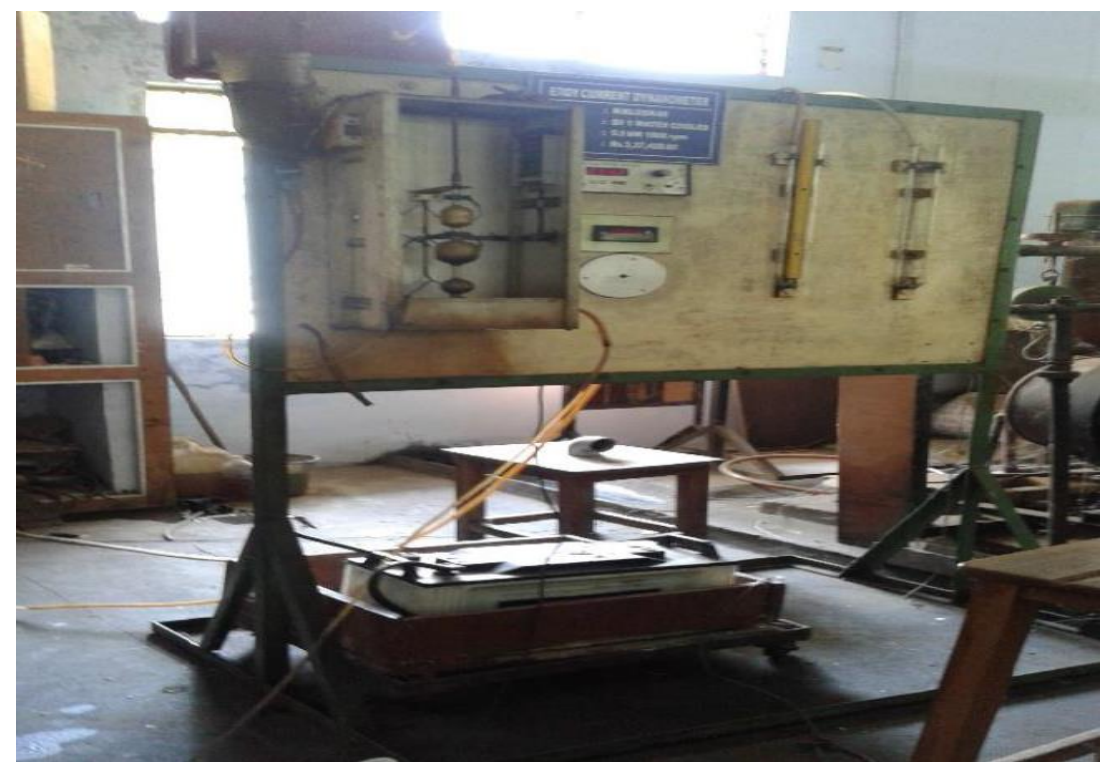

Fig. 3: Dynamometer

\subsection{Engine}

This engine we used a single cylinder water cooled engine. In this engine load act to electrical load due to it create potential difference. The fuel take from tank is passed through consumption timing of $50 \mathrm{ml}$ fuel in engine. In this way dynamometer and monometer readings are taken.

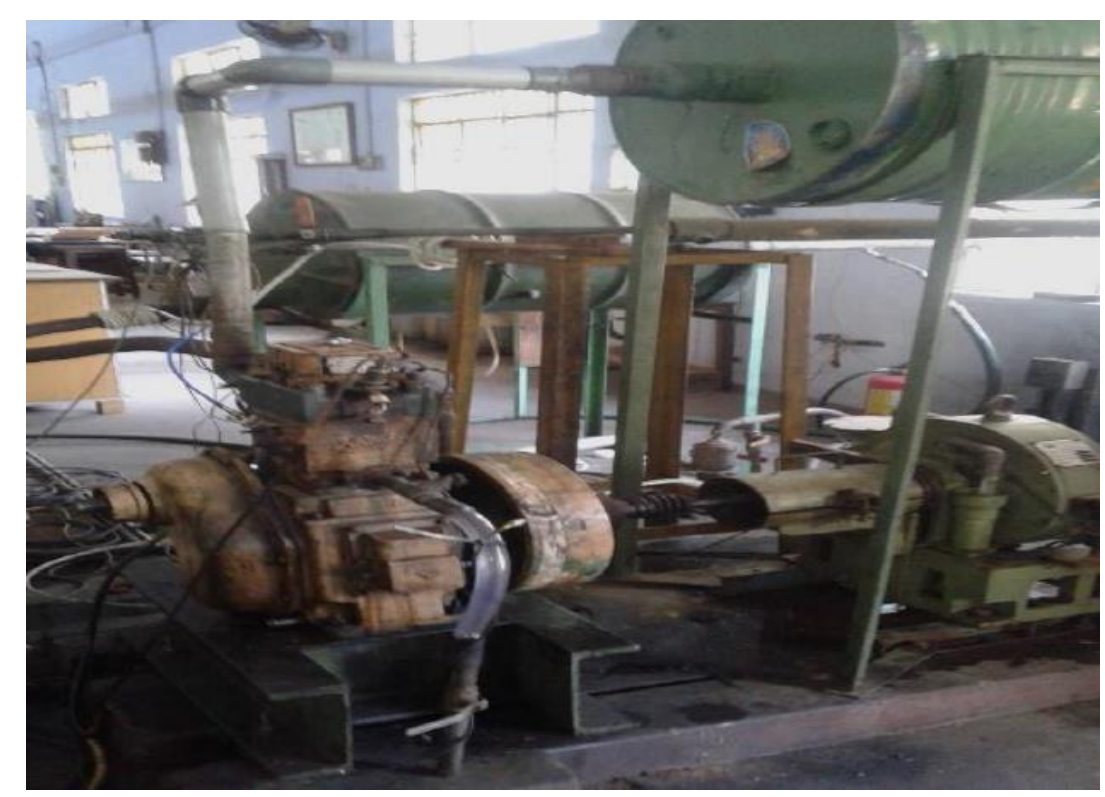

Fig. 4: Diesel Engine

\subsection{Load Controller}

In this we use a digital type load controller. The input is taken by potential electrical load method. The load indicator shows applied dynamometer for reading and to the engine for the cycle process. The exhaust gas is passed into an oxygen cylinder to measure the emission. 


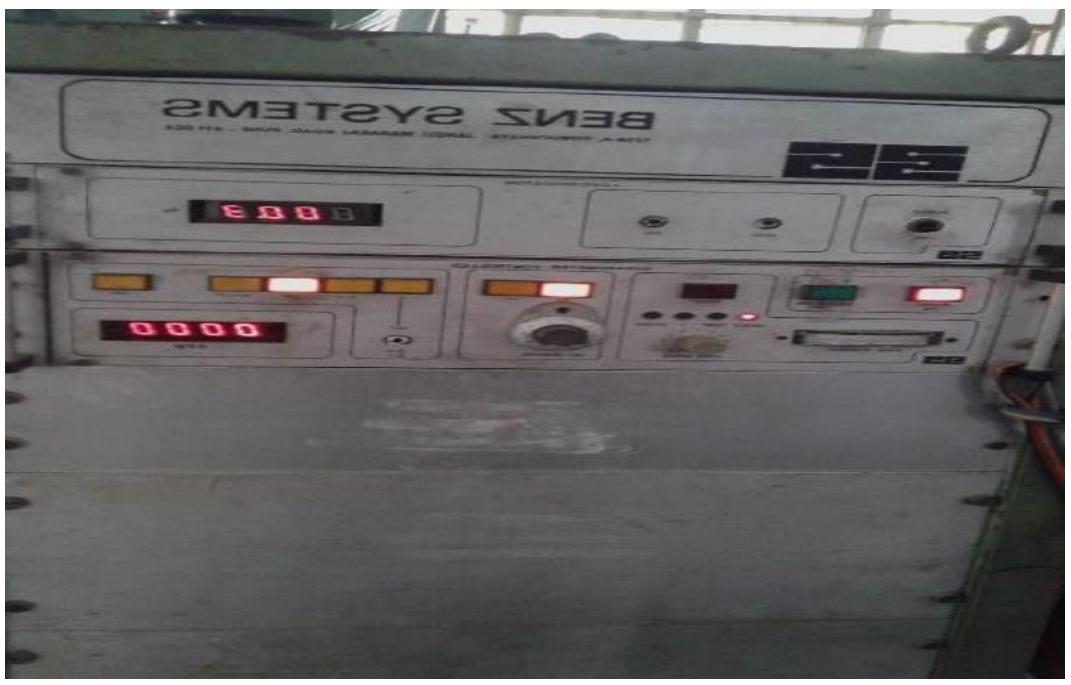

Fig. 5: Digital Load Controller

\subsection{Emission Sensing Unit}

In diesel engine, particulate matter a major role in exhaust pollutants. Particulate matter consider of substance, particles and water. The substance are removed of by filtering the gas the particular consider of carbon particles and unburned hydrocarbons which are absorbed by some organic compound, which we use

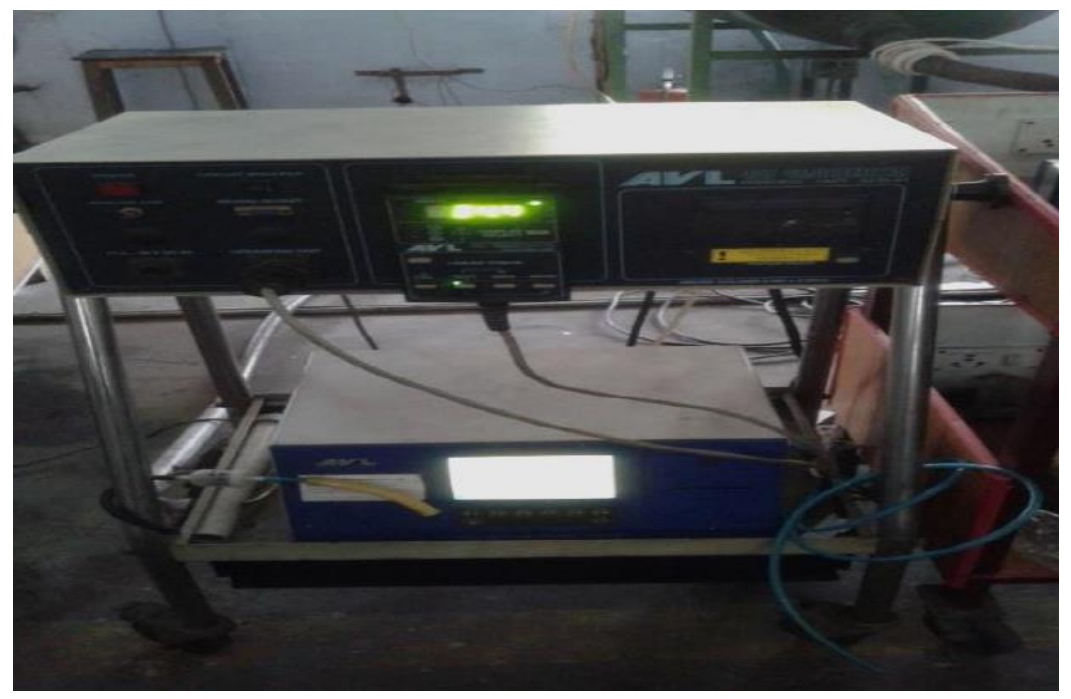

Fig. 6: Emission Sensing Unit

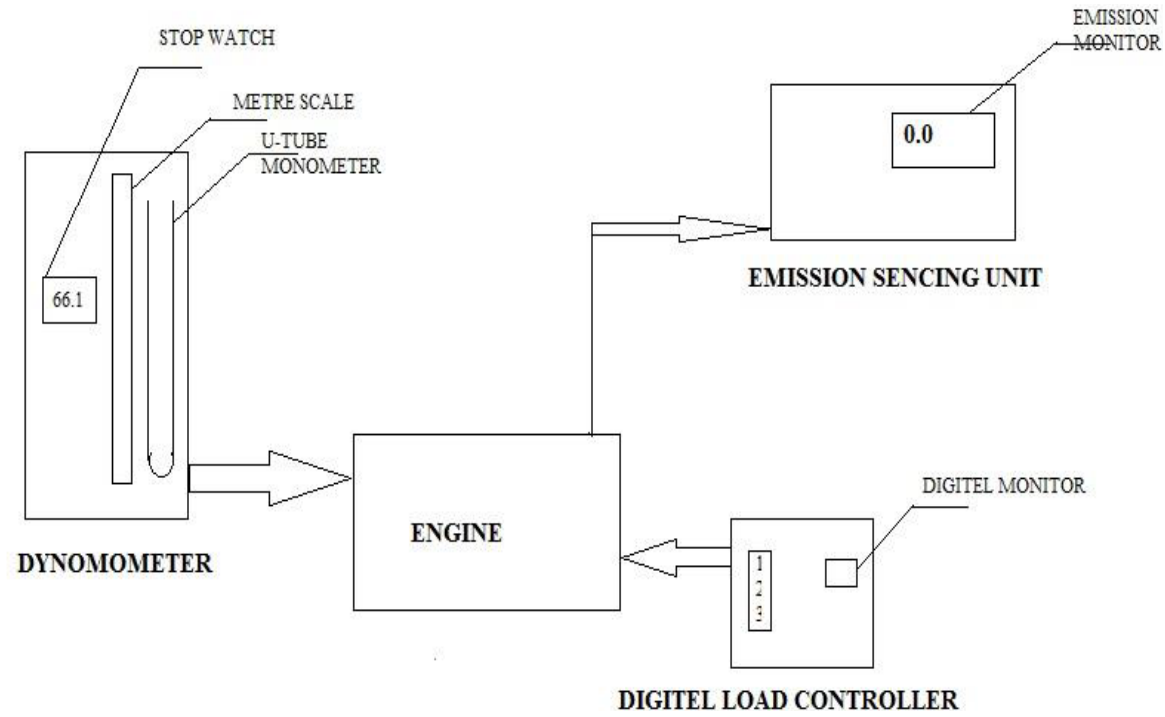

Fig. 7: Block Diagram of Experimental Engine setup 


\section{Experimental Setup of Diesel Engine}

We are used in the alternative fuel select the pongamia Bio diesel with diesel in different blending ratios. The ratios are

- Diesel $100 \%$

- Pongamia bio diesel 50\% and Diesel 50\%

- Pongamia bio diesel $100 \%$

In this project we used single cylinder four stroke diesel engine.

This engine cooled by the water. This engine connected with dynamometer. Also connected with emission sensor unit

\subsection{0 .1 D 100}

Diesel is filled in the fuel tank. Now the engine started. Initial load is $0 \mathrm{~kg}$ selected in the digital load controller. The fuel passed from the tank into the engine through the dynamometer. In the dynamometer the fuel consumption and the monometer reading are noted. Exhaust gas from the engine is passed to the oxygen cylinder through the drum. The oxygen cylinder connected to the emission control meter used to the exhaust gases and their particulate. Co, Co2, Nox, and smoke readings.

Then add load $1.8 \mathrm{~kg}$ to the load control then take above readings repeat the same procedure for different load conditions. The load conditions are, $1.8 \mathrm{~kg}, 3.6 \mathrm{~kg}, 5.4 \mathrm{~kg}, 7.2 \mathrm{~kg}$ and $9 \mathrm{~kg}$.

\subsection{0 .2 B 50}

The above same procedure repeat for the B50 composition and also noted the speed and emission parameters.

The load conditions are, $1.8 \mathrm{~kg}, 3.6 \mathrm{~kg}, 5.4 \mathrm{~kg}, 7.2 \mathrm{~kg}$ and $9 \mathrm{~kg}$

\subsection{0 .3 B 100}

Pongamia is filled in the fuel tank. The above same procedure repeat for the B100 composition and also noted the speed and emission parameters (K.Nantha Gopal et al, March 2015) [5] and (K.Nantha Gopal et al, June 2014) [6] and (S.V Baste et al, August 2013) [7].

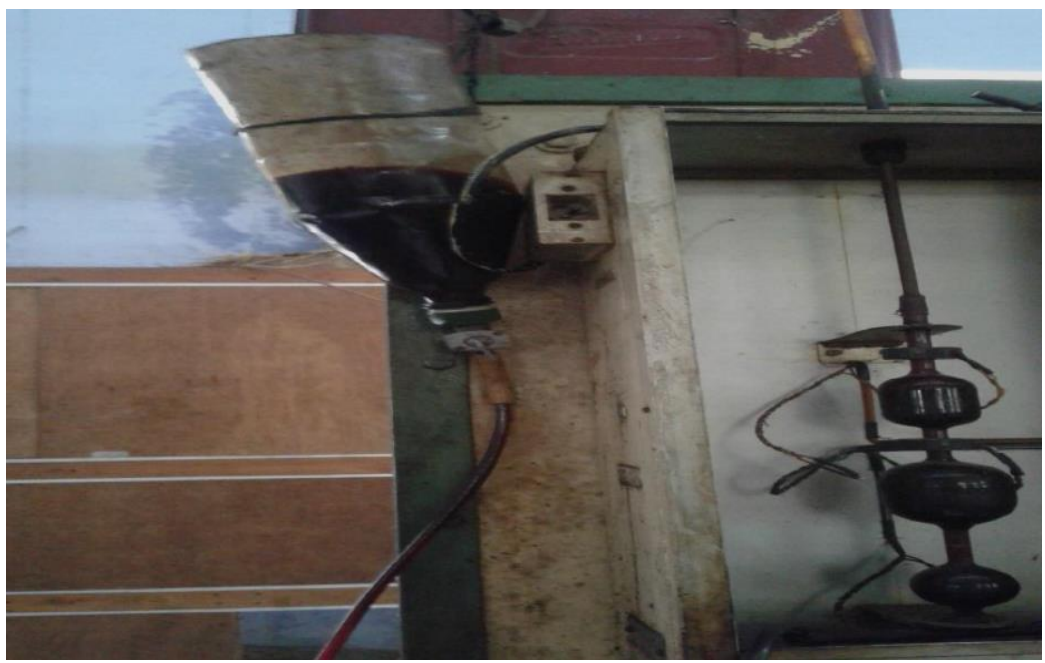

\section{Results and Discussion}

\subsection{Load vs Specific Fuel Consumption (D100, B50\& B100)}

In diesel engine consumption of the alternative fuel about D100, B50 and B100.In D100 at the engine runs at a load about $1.8 \mathrm{~kg}$ in
Fig. 8: Pongamia bio diesel

that load the specific fuel consumption is 0.5.In D50 the engine runs at same load of $1.8 \mathrm{~kg}$ in this specific fuel consumption is 0.51 but B100 composition the engine runs at the same load the specific fuel consumption is reduced to 0.45 due to this composition smoke and emission range is high.

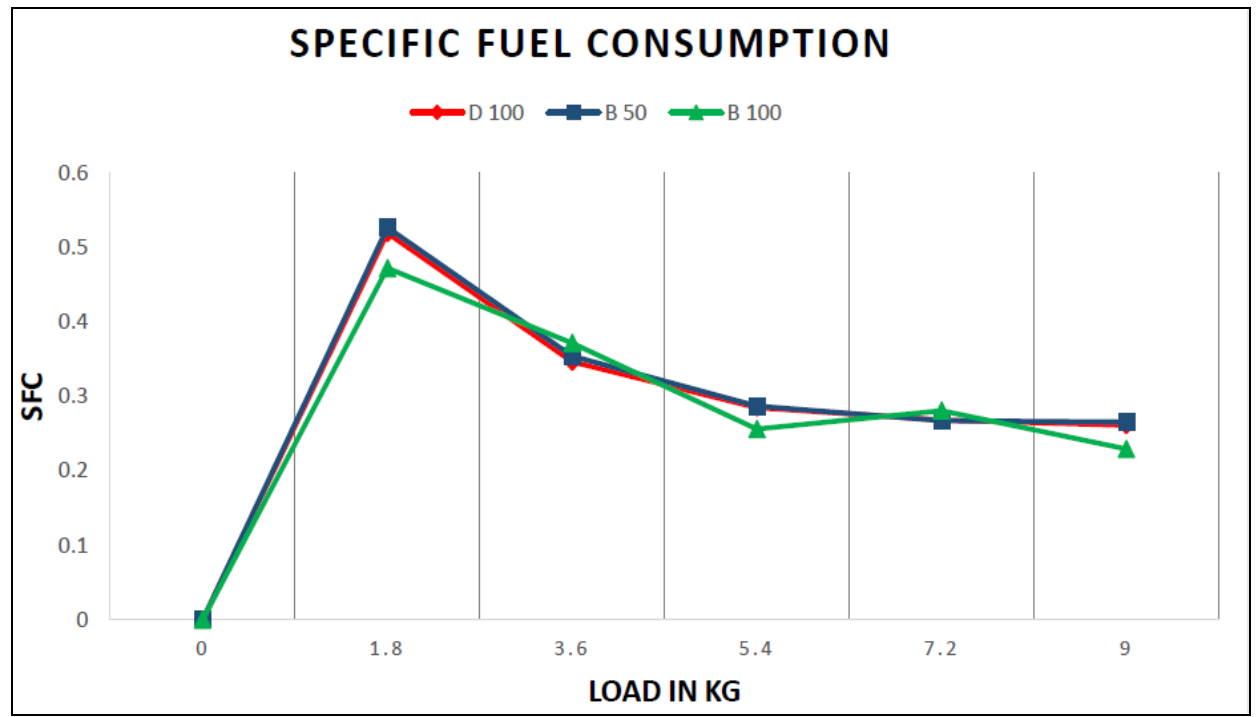




\subsection{Load vs Total Fuel Consumption (D 100,B 50, B100)}

The total fuel consumption $\mathrm{B} 100$ is 0.5 at the $1.8 \mathrm{~kg}$ and it is increase step by step for various load change up to $9 \mathrm{~kg}$ of load the total fuel consumption is 2.4.In B50 fuel tfc is 0.5 at $1.8 \mathrm{~kg}$ and increase 2.6at the load of 9kg.But D100 tfc is same as B50 tfc at $1.8 \mathrm{~kg}$ of load and its increase to 2.5 at the load of $9 \mathrm{~kg}$. It is slightly less than B100 at $9 \mathrm{~kg}$ of load. The total fuel consumption $\mathrm{B} 100$ is 0.5 at the $1.8 \mathrm{~kg}$ and it is increase step by step for various load change up to $9 \mathrm{~kg}$ of load the total fuel consumption is 2.4.In B50 fuel tfc is 0.5 at $1.8 \mathrm{~kg}$ and increase 2.6 at the load of $9 \mathrm{~kg}$.But $\mathrm{D} 100 \mathrm{tfc}$ is same as B50 tfc at $1.8 \mathrm{~kg}$ of load and its increase to 2.5 at the load of $9 \mathrm{~kg}$. It is slightly less than B100 at $9 \mathrm{~kg}$ of load.

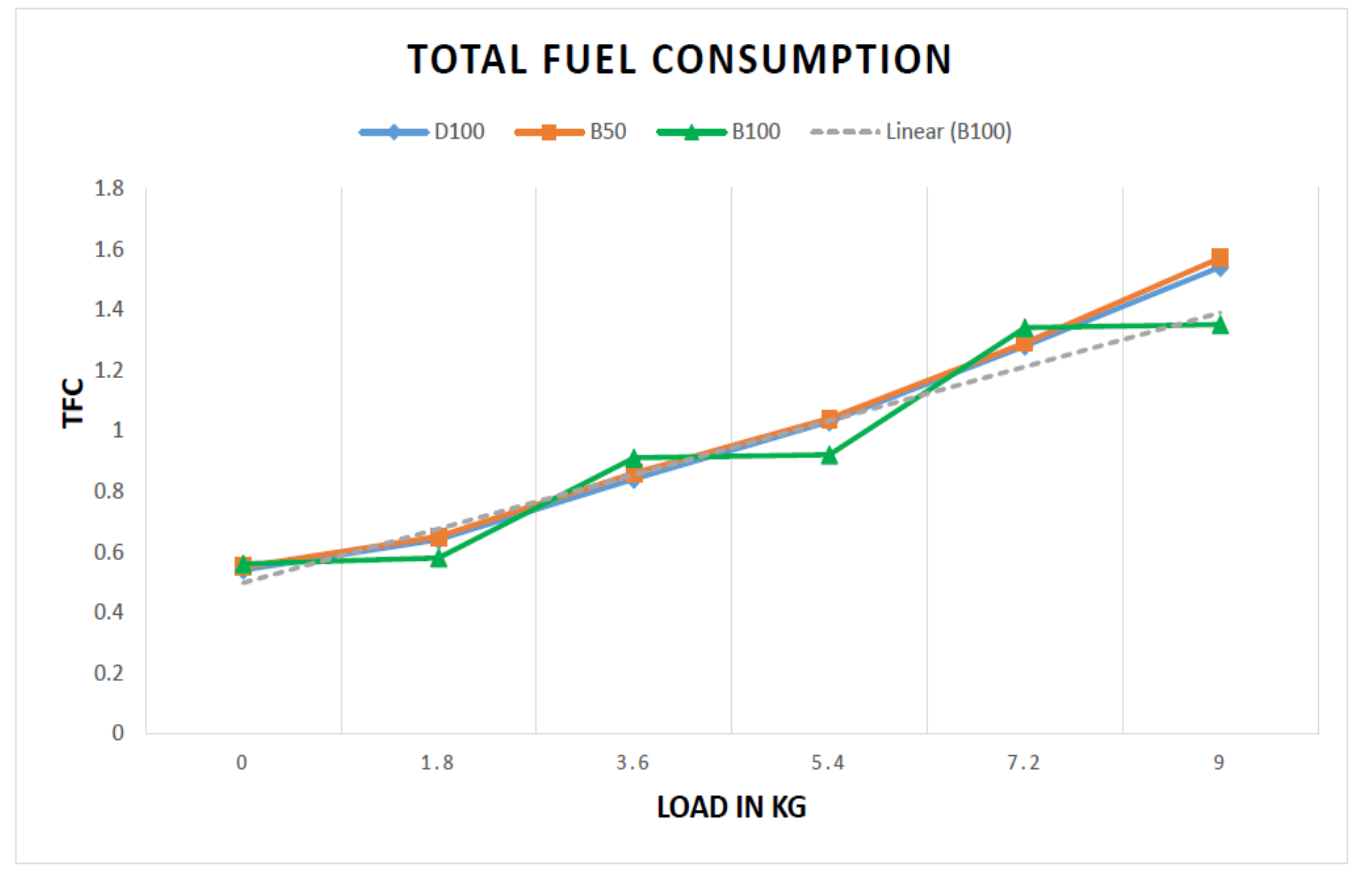

\subsection{Load vs Efficiency (D 100,B 50,B 100)}

and it is increase $30 \%$ but in D100 efficiency is $15 \%$ of at the load

In B100 the efficiency $17 \%$ of load at $1.8 \mathrm{~kg}$ and at $9 \mathrm{~kg}$ it is $1.8 \mathrm{~kg}$ and it is increase $32 \%$ at the load $9 \mathrm{~kg}$. increase to $35 \%$.In B50 the efficiency is $15 \%$ at the load $1.8 \mathrm{~kg}$

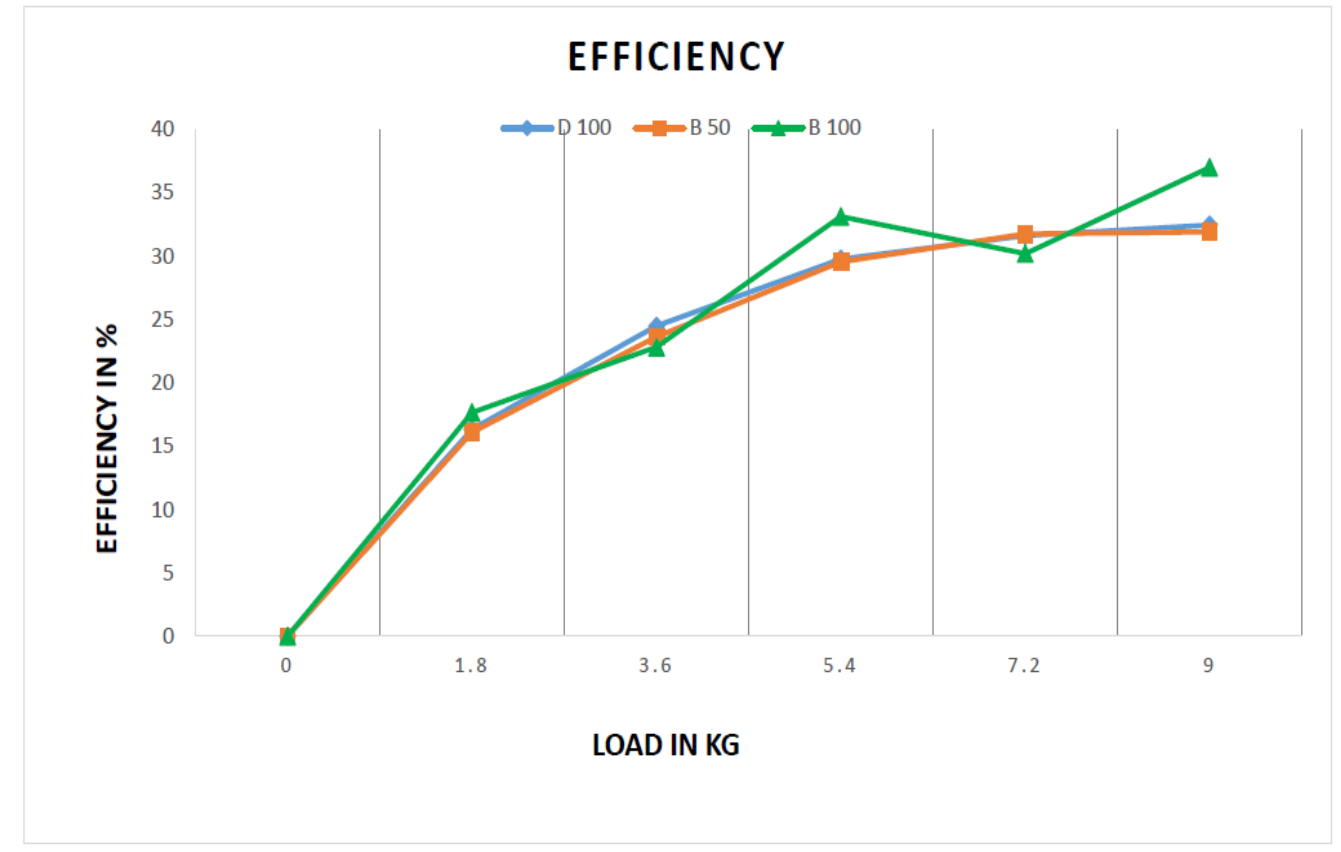

\subsection{Carbon Monoxide for D100,B50 AND B100}

Carbon monoxide is $0.07 \mathrm{ppm}$ at the load of $1.8 \mathrm{~kg}$ in B100and its increase to $0.09 \mathrm{ppm}$ at the load $9 \mathrm{~kg}$. In $\mathrm{B} 50$ ratio the carbon monoxide is less than B50 in $0.06 \mathrm{ppm}$ and decreased in $5.4 \mathrm{~kg}$. The $\mathrm{B} 100$ carbon monoxide value is high compare to B50 and D100. 


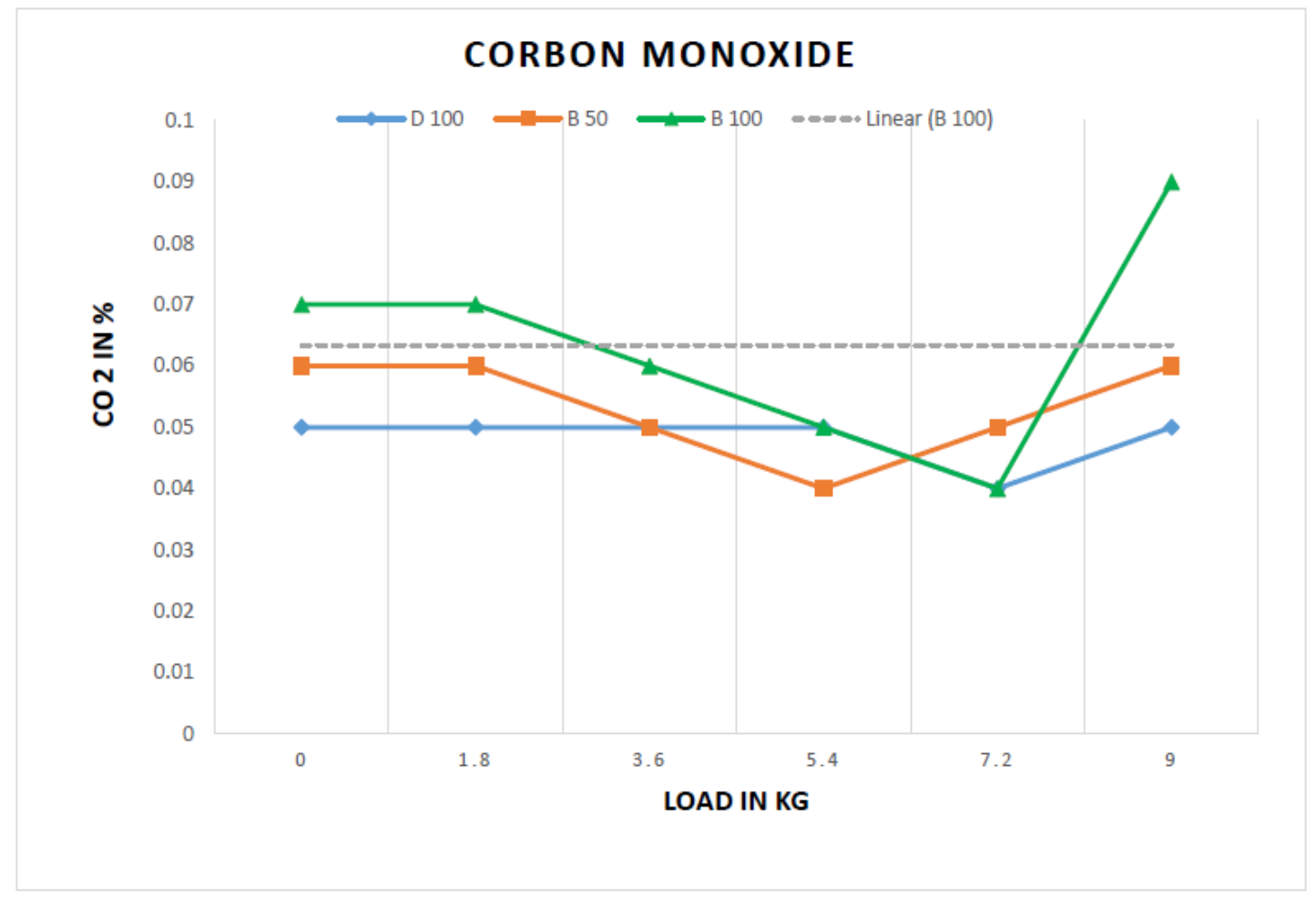

\subsection{Carbon Dioxide for D100, B50 and B100}

Carbon dioxide is $2.5 \mathrm{ppm}$ for $1.8 \mathrm{~kg}$ and increase to $10.5 \mathrm{ppm}$ at the load of $9 \mathrm{~kg}$ for B100.In the B50 carbon dioxide is $2.5 \mathrm{ppm}$ at the load of $1.8 \mathrm{~kg}$ and it increase $10 \mathrm{ppm}$ at the load of $9 \mathrm{~kg}$.But D100 the carbon dioxide level is $3 \mathrm{ppm}$ at the load $1.8 \mathrm{~kg}$ and it is increase $10 \mathrm{ppm}$ at the load of $9 \mathrm{~kg}$.

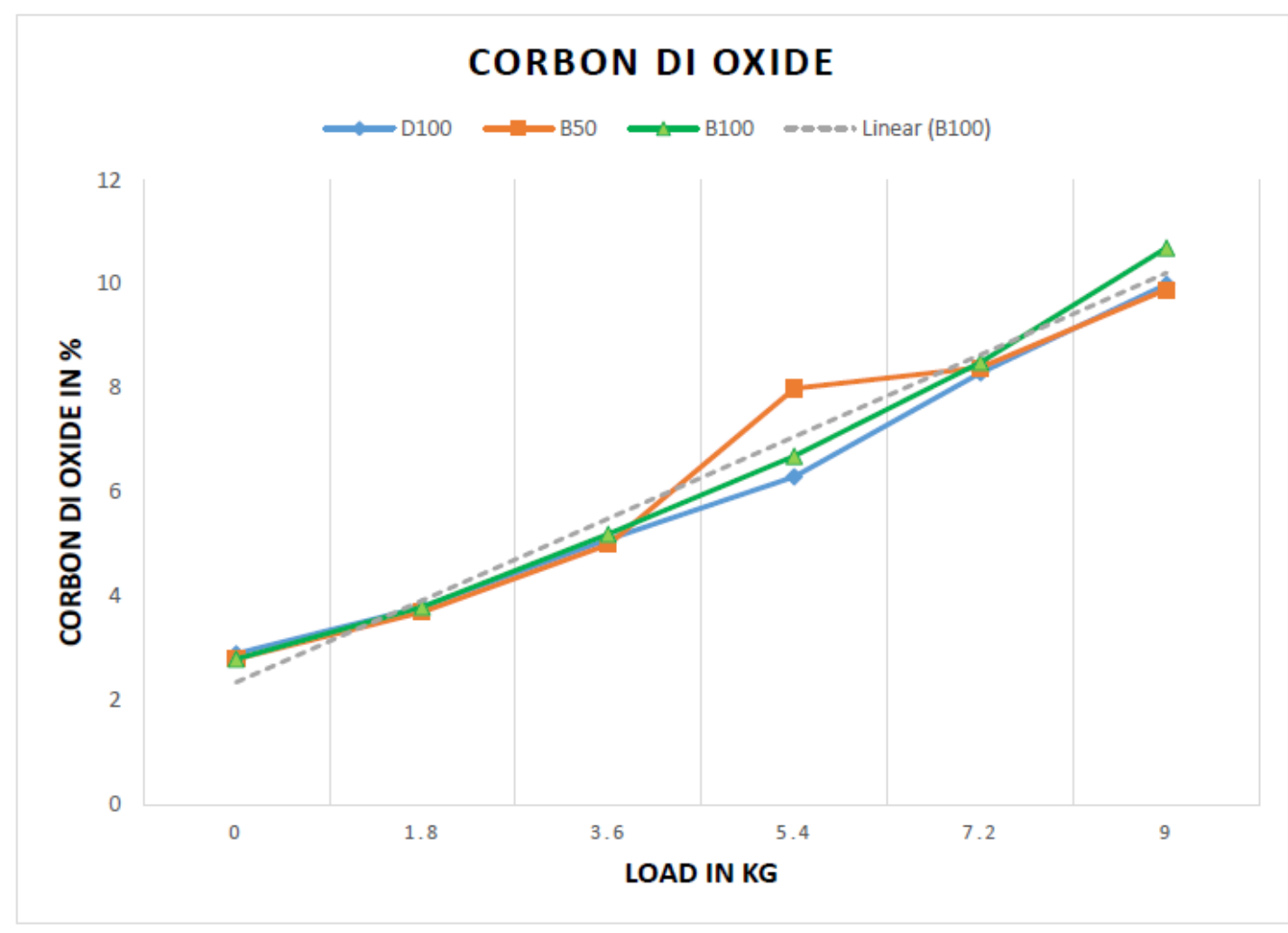

\subsection{Hydro Carbon for D100,B50 and B100}

In the B100 hydro carbon in $52 \mathrm{ppm}$ at the load $1.8 \mathrm{~kg}$ and it is increase to $70 \mathrm{ppm}$ at the load $9 \mathrm{~kg}$. In the B50 hydro carbon in 57 ppm at the load $1.8 \mathrm{~kg}$ and it is increase to $80 \mathrm{ppm}$ at the load $9 \mathrm{~kg}$. In the D100 hydro carbon in $68 \mathrm{ppm}$ at the load $1.8 \mathrm{~kg}$ and it is increase to $99 \mathrm{ppm}$ at the load $9 \mathrm{~kg}$. 


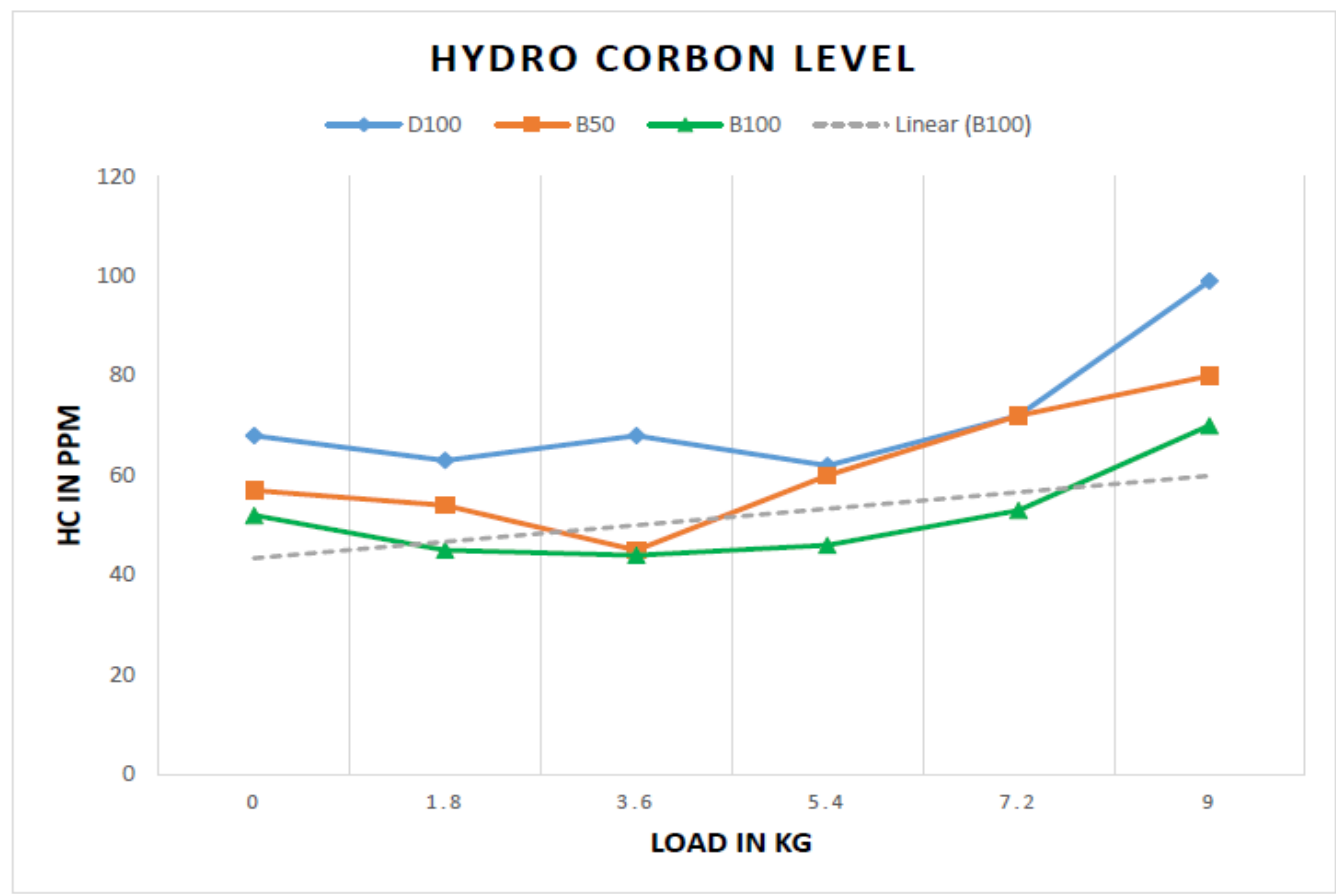

\subsection{Nox for D100, B50 and B100}

In the B100 Nox in $110 \mathrm{ppm}$ at the load $1.8 \mathrm{~kg}$ and it is increase to $801 \mathrm{ppm}$ at the load $9 \mathrm{~kg}$. In the B50 Nox in $110 \mathrm{ppm}$ at the load
$1.8 \mathrm{~kg}$ and it is increase to $780 \mathrm{ppm}$ at the load $9 \mathrm{~kg}$. In the D100 Nox in $110 \mathrm{ppm}$ at the load $1.8 \mathrm{~kg}$ and it is increase to $711 \mathrm{ppm}$ at the load $9 \mathrm{~kg}$.

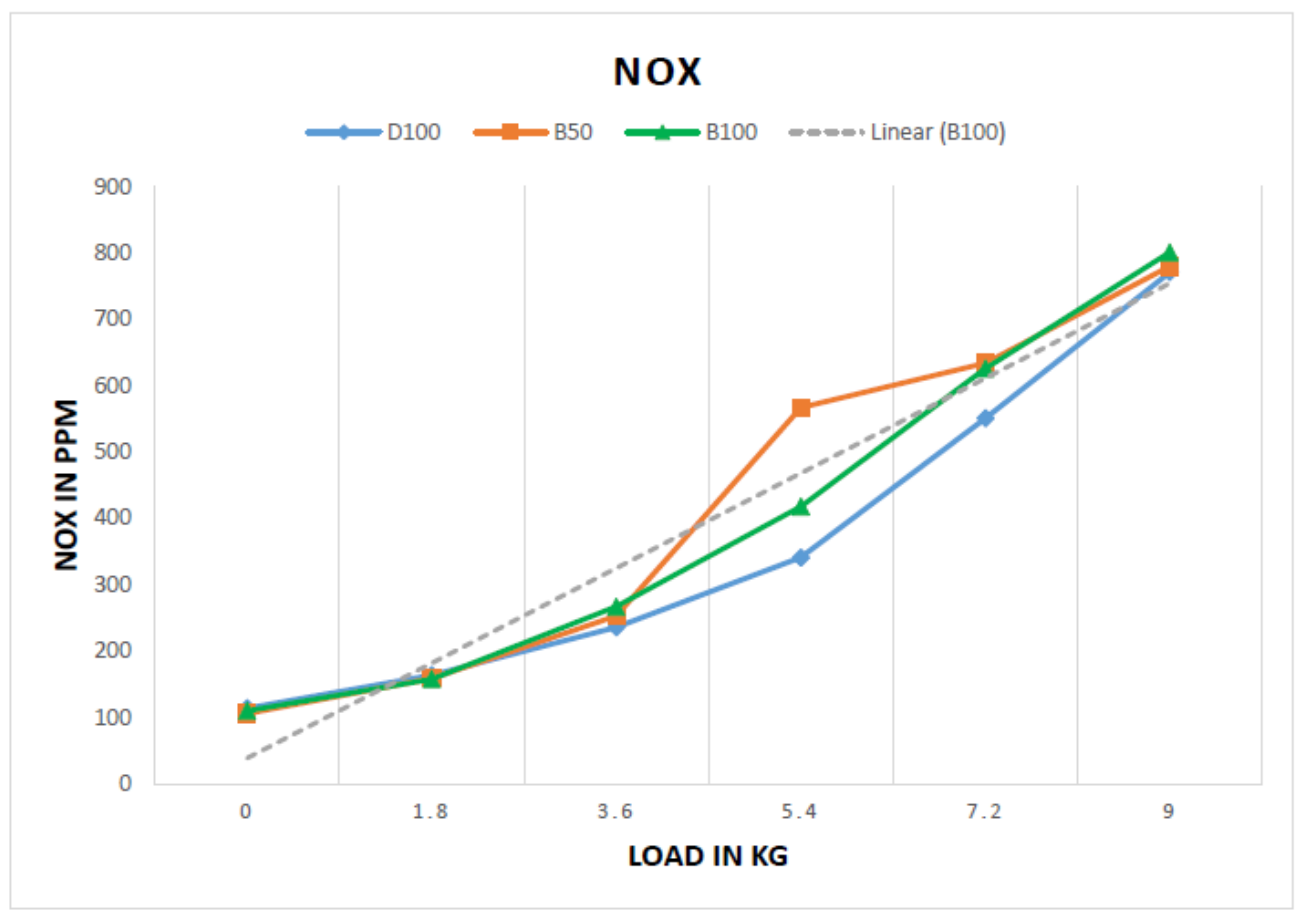

\subsection{Smoke for D100,B50 and B100}

In the B100 smoke percentage is $41.3 \%$ at the load $1.8 \mathrm{~kg}$ and it is increase to $90 \%$ at the load $9 \mathrm{~kg}$. In the B50 smoke percentage is
$38 \%$ at the load $1.8 \mathrm{~kg}$ and it is increase to $80 \%$ at the load $9 \mathrm{~kg}$. In the D100 smoke percentage is $23 \%$ at the load $1.8 \mathrm{~kg}$ and it is increase to $72 \%$ at the load $9 \mathrm{~kg}$. 


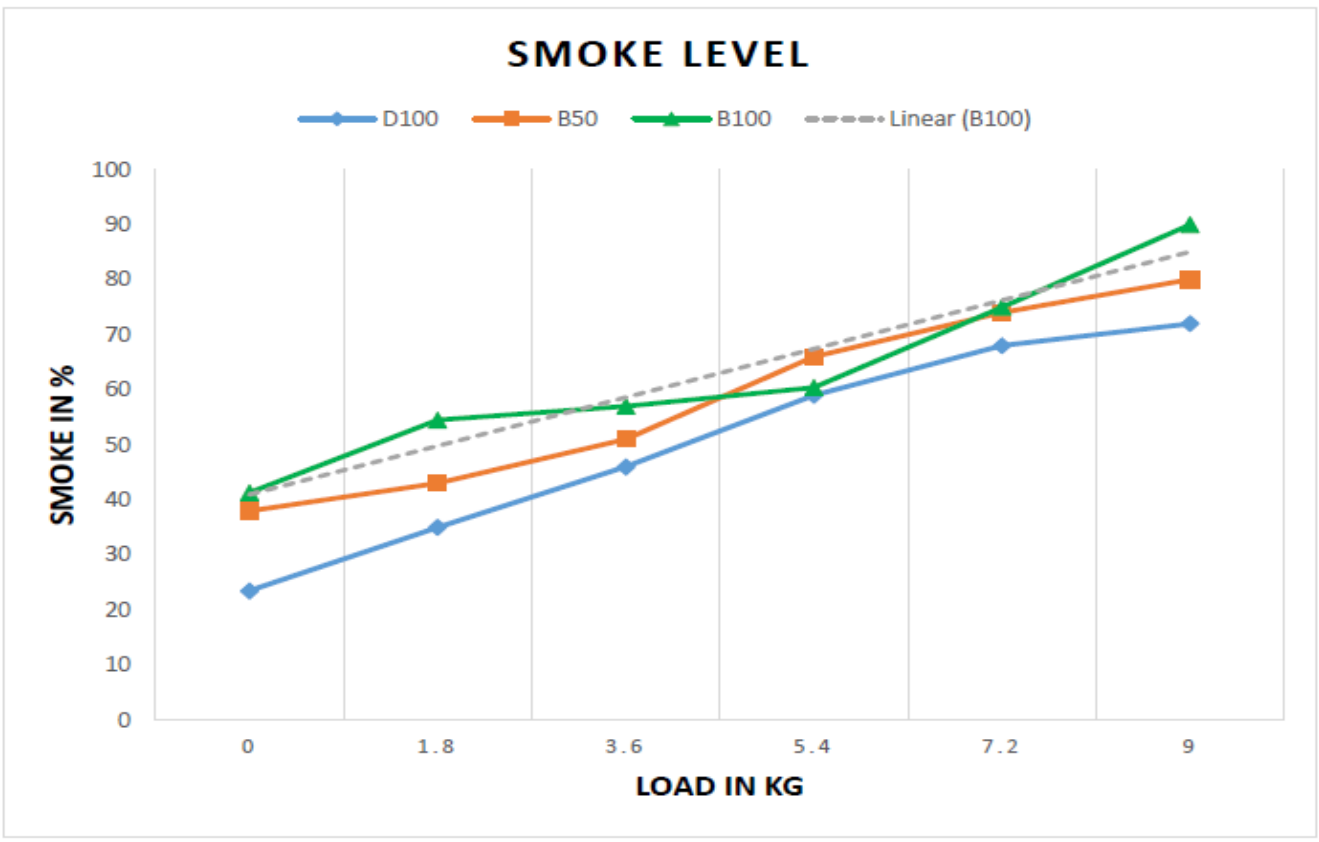

\section{References}

[1] MalayaNaik et al., "Production of biodiesel from high free fatty acid Karanja (Pongamia pinnata) oil", Biomass and Bioenergy, Volume 32, Issue 4, April 2008, Pages 354-357.

[2] M Rakib Uddin et al., "Preparation of Biodiesel From Karanja (Pongamia Pinnata) Oil”, J. of Chem Engg, Vol. 29, No. 1, 2017: 24-28.

[3] S.N Bobade et al., "Preparation of Methyl Ester (Biodiesel) from Karanja (Pongamia Pinnata) Oil”, Research Journal of Chemical Sciences,Vol. 2(8), 43-50, August 2012.

[4] Arun K. Vuppaladadiyam et al., "Transesterification of Pongamia pinnata Oil Using Base Catalysts: A Laboratory Scale Study," Universal Journal of Environmental Research and Technology, Volume 3, Issue 1: 113-118.

[5] K.Nantha Gopalet al., "Effect of pongamia biodiesel on emission and combustion characteristics of DI compression ignition engine", Ain Shams Engineering Journal, Volume 6, Issue 1, March 2015, Pages 297-305.

[6] K.Nantha Gopal et al., "Investigation of emissions and combustion characteristics of a CI engine fueled with waste cooking oil methyl ester and diesel blends"Alexandria Engineering Journal, Volume 53, Issue 2, June 2014, Pages 281-287.

[7] S.V Baste et al.,"Emission Characteristics of Pongamia Pinnata (Karanja) Biodiesel and Its Blending up to $100 \%$ in a C.I. Engine", Res. J. Agriculture \& Forestry Sci., Volume 1, Issue (7), Pages 1-5, August, 8 (2013).

[8] R. Sathish Kumar et al., "Effect of methanol blending with Pongamia pinnata biodiesel and diesel blends on engine performance and exhaust emission characteristics of an unmodified Compression Ignition engine", International Journal of Ambient Energy, Volume 36, 2015 - Issue 2

[9] Gaurav Dwivedi et al.,"Pongamia as a Source of Biodiesel in India”Smart Grid and Renewable Energy, Volume 2, Issue 3, PP. 184-189, August 2011.

[10] M H Attal et al., "Critical Analysis of Performance of Compression Ignition Engine for Biodiesel with Exhaust Gas Recirculation", International Journal of Current Engineering and Technology, Vol.6, No.5 (Oct 2016), PP. 1568-1572.

[11] R. Kalaivani, K. Ramash Kumar, S. Jeevananthan, "Implementation of VSBSMC plus PDIC for Fundamental Positive Output Super Lift-Luo Converter," Journal of Electrical Engineering, Vol. 16, Edition: 4, 2016, pp. 243-258.

[12] K. Ramash Kumar,'Implementation of Sliding Mode Controller plus Proportional Integral Controller for Negative Output Elementary Boost Converter," Alexandria Engineering Journal (Elsevier), 2016, Vol. 55, No. 2, pp. 1429-1445.

[13] P. Sivakumar, V. Rajasekaran, K. Ramash Kumar, "Investigation of Intelligent Controllers for Varibale Speeed PFC Buck-Boost
Rectifier Fed BLDC Motor Drive," Journal of Electrical Engineering (Romania), Vol.17, No.4, 2017, pp. 459-471.

[14] K. Ramash Kumar, D.Kalyankumar, DR.V.Kirbakaran” An Hybrid Multi level Inverter Based DSTATCOM Control, Majlesi Journal of Electrical Engineering, Vol. 5. No. 2, pp. 17-22, June 2011, ISSN: 0000-0388.

[15] K. Ramash Kumar, S. Jeevananthan, "A Sliding Mode Control for Positive Output Elementary Luo Converter," Journal of Electrical Engineering, Volume 10/4, December 2010, pp. 115-127.

[16] K. Ramash Kumar, Dr.S. Jeevananthan," Design of a Hybrid Posicast Control for a DC-DC Boost Converter Operated in Continuous Conduction Mode" (IEEE-conference PROCEEDINGS OF ICETECT 2011), pp-240-248, 978-1-42447925-2/11.

[17] K. Ramash Kumar, Dr. S. Jeevananthan," Design of Sliding Mode Control for Negative Output Elementary Super Lift Luo Converter Operated in Continuous Conduction Mode", (IEEE conference Proceeding of ICCCCT-2010), pp. 138-148, 978-1-4244-7768$5 / 10$.

[18] K. Ramash Kumar, S. Jeevananthan, S. Ramamurthy" Improved Performance of the Positive Output Elementary Split InductorType Boost Converter using Sliding Mode Controller plus Fuzzy Logic Controller, WSEAS TRANSACTIONS on SYSTEMS and CONTROL, Volume 9, 2014, pp. 215-228.

[19] N. Arunkumar, T.S. Sivakumaran, K. Ramash Kumar, S. Saranya, "Reduced Order Linear Quadratic Regulator plus Proportional Double Integral Based Controller for a Positive Output Elementary Super Lift Luo-Converter," JOURNAL OF THEORETICAL AND APPLIED INFORMATION TECHNOLOGY, July 2014. Vol. 65 No.3, pp. 890-901.

[20] Arunkumar, T.S. Sivakumaran, K. Ramash Kumar, "Improved Performance of Linear Quadratic Regulator plus Fuzzy Logic Controller for Positive Output Super Lift Luo-Converter," Journal of Electrical Engineering, Vol. 16, Edition:3, 2016, pp. 397-408. 